\section{Цитування:}

Касьяненко А. С. Креативний компонент як невід'ємна складова фахової підготовки майбутніх режисерів естради. Вісник Національної академії керівних кадрів культури $i$ мистеитв : наук. журнал. 2020. №3. С.274-279.

Kasianenko, A. (2020). Creative component as an integral part of the professional training of future stage directors. National Academy of Culture and Arts Management Herald: Science journal, 3, 274279 [in Ukrainian].

\author{
Касьяненко Андрій Серхійович, \\ викладач кафедри режисури естради \\ та масових свят Київського начіонального \\ університету культури і мистеитв \\ ORCID: https://orcid.org/0000-0001-6085-2190 \\ andriikasianenko@ukr.net
}

\title{
КРЕАТИВНИЙ КОМПОНЕНТ ЯК НЕВІД'СМНА СКЛАДОВА ФАХОВОЇ ПІДГОТОВКИ МАЙБУТНІХ РЕЖИСЕРІВ ЕСТРАДИ
}

Мета статті - комплексний аналіз головних особливостей та чинників креативного компонента як невід’ємної складової фахової підготовки майбутніх режисерів естради. Окреслити роль професійної креативної освіти у формуванні творчої особистості бакалаврів-режисерів естради, як майбутніх фахівців сучасної української івент-індустрії. Методологія дослідження полягає у застосуванні аналітичного, мистецтвознавчого, порівняльного й системного методів дослідження головних особливостей та чинників креативного компонента у підготовці майбутніх режисерів естради. Для досягнення визначеної мети i розв'язання поставлених завдань використано аналіз науково-методичних джерел, узагальнення науковопедагогічного досвіду 3 питань професійної підготовки майбутніх режисерів естради. Наукова новизна дослідження виявляється в тому, що воно є першою спробою системного аналізу креативного компонента як невід'ємної складової підготовки майбутніх режисерів естради на основі багатолітнього творчого досвіду автора, як артиста і режисера. Висновки. Розглянуто головні особливості та чинники формування креативної компетентності фахової підготовки студентів за першим (бакалаврським) рівнем вищої освіти, за спеціалізацією «Режисура естради та масових свят» спеціальності 026 «Сценічне мистецтво», для яких творчі здібності $є$ важливою професійною якістю та невід'ємною складовою фахової компетентності. Встановлено, що формування креативного творчого мислення стимулює мотиваційний компонент, який розвиває пошукову самостійність і здатність долати труднощі, сприяє прагненню до досягнення кінцевого результату. Зазначено, що неприпустимими є уніфікація студентів, стирання творчих особливостей особистості. Обгрунтовано, що домінуючою особливістю креативного компонента в підготовці майбутнього режисера естради $є$ високий рівень творчого саморозвитку особистості, що $\epsilon$ істотним резервом iіi самоактуалізації до професійної діяльності.

Ключові слова: креативний компонент, бакалавр, режисер, естрада, творче мислення, самоактуалізація, видовищне дійство, івент-індустрія.

Касьяненко Андрей Сергеевич, преподаватель кафедры режиссуры эстрады и массовых праздников Киевского национального университета культуры и искусств

Креативный компонент как неотьмлемая составляющая профессиональной подготовки будущих режиссеров эстрады

Цель статьи - комплексный анализ главных особенностей и факторов креативного компонента как неотъемлемой составляющей профессиональной подготовки будущих режиссеров эстрады. Обозначить роль профессионального креативноо образования в формировании творческой личности бакалавров-режиссеров эстрады, как будущих специалистов современной украинской ивент-индустрии. Методология исследования заключается в применении аналитического, искусствоведческого, сравнительного и системного методов исследования главных особенностей и факторов креативного компонента в подготовке будущих режиссеров эстрады. Для достижения поставленной цели и решения поставленных задач использованы анализ научнометодических источников, обобщение научно-педагогического опыта по вопросам профессиональной подготовки будущих режиссеров эстрады. Научная новизна исследования заключается в том, что оно является первой попыткой системного анализа креативного компонента как неотъемлемой составляющей подготовки будущих режиссеров эстрады на основе многолетнего творческого опыта автора, как артиста и режиссера. Выводы. Рассмотрены основные особенности и факторы формирования креативной компетентности профессиональной подготовки студентов бакалавриата по специализации «Режиссура эстрады и массовых

(C) Касьяненко А. С., 2020 


\section{Вісник Національної академії керівних кадрів культури і мистецтв № 3’2020}

праздников» специальности 026 «Сценическое искусство», для которых творческие способности являются главным профессиональным качеством и неотъемлемой составляющей профессиональной компетентности. Установлено, что формирование креативного творческого мышления стимулирует мотивационный компонент, который развивает поисковую самостоятельность и способность преодолевать трудности, способствует стремлению к достижению конечного результата. Отмечено, что недопустимы унификация студентов, стирание творческих особенностей личности. Обосновано, что доминирующей особенностью креативного компонента в подготовке будущего режиссера эстрады является высокий уровень творческого саморазвития личности, что является существенным резервом ее самоактуализации в профессиональной деятельности.

Ключевые слова: креативный компонент, бакалавр, режиссер, эстрада, творческое мышление, самореализация, зрелищное действо, ивент-индустрия.

Kasianenko Andrii, a lecturer at the Department of Directing Shows and Mass Holidays at the Kyiv National University of Culture and Arts

Creative component as an integral part of the professional training of future stage directors

The purpose of the article is a comprehensive analysis of the main features and factors of the creative component as an integral part of the professional training of future stage directors. To highlight the role of professional creative education in the formation of a creative personality of the Film Director Bachelors as the future specialists of the contemporary Ukrainian event industry. The methodology of the research is to apply analytical, art-study, comparative, and systematic methods of studying the main features and factors of the creative component in the training of future filmmakers. To achieve a certain goal and to solve the tasks, the analysis of scientific and methodological sources, the generalization of scientific and pedagogical experience on the issues of professional training of future stage directors is used. The scientific novelty of the study is that it is the first attempt of systematic analysis of the creative component as an integral part of the training of future stage directors based on the author's many years of creative experience as an artist and director. Conclusions. The main features and factors of the formation of the creative competence of students' professional training in the first (bachelor) level of higher education, specialization "The Director of the Stage and Mass Festivals" of the specialty 026 "Stage Art" are reviewed; the creative abilities for the students are important professional quality and an integral part of the professional competence. It has been established that the formation of creative thinking stimulates the motivational component, which develops search independence and the ability to overcome difficulties, promotes the pursuit of the final result. It is noted that the unification of students, effacement of creative personality peculiarities is unacceptable. It is substantiated that the dominant feature of the creative component in the preparation of the future stage director is the high level of creative self-development of the personality, which is an essential reserve of its self-actualization to professional activity.

Key words: creative component, bachelor, director, stage, creative thinking, self-actualization, spectacle action, event industry.

Актуальність теми дослідження. Креативність сьогодні виходить на перший план у життєвому просторі молодого покоління. Творчі особистості цінуються, а характерні якості креативності перебувають на перших позиціях. Креативність (латин. creatio - створення) - творча, новаторська діяльність; новітній термін, яким окреслюються «творчі здібності індивіда, що характеризуються здатністю до продукування принципово нових ідей і входять в структуру обдарованості як незалежний фактор» $[5,2]$.

Синтетична специфіка сучасного українського естрадного мистецтва вимагає особливих режисерських втілень, інтегративний характер яких спонукає до універсальної підготовки митця, спроможного володіти усіма компонентами видовищного синтезу. Як зазначав сучасний український дослідник В.Зайцев: «Майбутнє української естради багато в чому залежить від рівня професійної, естетичної, етичної зрілості молоді, яка приходить в режисуру естради» $[4,5]$. Тільки комплексний, інтегративний характер мистецької підготовки режисера естради дозволить виховати кваліфікованого фахівця, спроможного синтезувати різні види мистецтва для створення оригінальних творів, які поєднуватимуть традиції і новації, кращий зарубіжний досвід 3 національними здобутками.

Нагальною потребою сьогодення стає потреба вдосконалення системи професійної підготовки майбутніх фахівців, що мають високий креативний потенціал, володіють законами режисури, основами маркетингу та PR; обізнані в галузях культури і мистецтва; адаптовані до сучасних умов i вимог ринку праці. Важливість та складність окреслених завдань щодо формування креативної компетентності у бакалаврів-режисерів естради, як майбутніх фахівців сучасної української івент-індустрії, посилюють актуальність даного дослідження.

Аналіз досліджень і публікацій. Проблемі дослідження творчості і креативності зокрема, присвячено чимало монографій і статей вчених, педагогів, психологів, філософів. Так, 
загальні питання формування творчої особистості досліджували О.Бех, Л. Виготський, В. Крутецький, I. Зимня, Г. Леонтьєв, Т. Лубенець О.Костюк, С. Рубінштейн.

Процес творчості, сутність творчої діяльності, iii етапи та методи розглядали С. Альтшулер, А. Горальський, О. Матейко, В. Романець, Розумовський, О. Тихомиров, Я. Пономарьов, В. Шубинський, С. Сисоєва та ін.

Методологія дослідження грунтується на аналізі мистецтвознавчого, порівняльного й системного методів дослідження головних особливостей та чинників креативного компонента у підготовці майбутніх режисерів естради. Так, на сьогодні, не існує єдиного визначення поняття «креативності» як вітчизняними, так і зарубіжними науковцями.

Аналіз наукових джерел, присвячених дослідженню різних аспектів, дають нам змогу системно проаналізувати та глибше розкрити його специфічні особливості, зокрема, зарубіжні вчені Е. де Боно, Д. Дюфо, Дж. Гілфорд, А. Маслоу, Е. Фром стверджують, що креативне мислення - це навичка, яку може розвинути кожна особистість, починаючи 3 раннього віку.

Креативні техніки в контексті розвитку творчого потенціалу, творчих здібностей особистості репрезентовано в працях таких зарубіжних дослідників, як Дж. Л. Адамс, Е. де Боно, Р. Ділтс, Х. Йоас, Б. Клег, Р. Крачфілд, М. Микалко, М. Ньольке, П. Слоан, С. Торп, Й. Шерер та ін., вітчизняних науковців А. Грецова, С. Комарова, Н. Рождественської та ін. Слід зауважити на тому, що не всі вітчизняні i зарубіжні вчені достатньо приділяли і приділяють увагу питанню впливу креативної педагогіки на формування у студентів професійної спрямованості, іiі особливої значущості, специфічної професійної поведінки, професійної етики, майстерності, індивідуального стилю, відповідальності [8, 215].

Проте проблема формування креативної компетентності як невід'ємної складової фахової підготовки майбутніх режисерів естради розроблена ще недостатньо повно і не знайшла достатнього висвітлення в сучасних наукових дослідженнях, незважаючи на іiі значущість для теорії й практики професійної освіти.

Мета дослідження - комплексний аналіз головних особливостей та чинників креативного компонента як невід'ємної складової фахової підготовки майбутніх режисерів естради. Окреслити роль професійної креативної освіти у формуванні творчої особистості бакалаврів-режисерів естради, як майбутніх фахівців сучасної української івент-індустрії.

Виклад основного матеріалу. В сучасній вищій мистецькій освіті саме креативні освітні технології виступають важливим фактором у процесі постійного духовно-творчого удосконалення особистості, формування інтелектуального i культурного потенціалу майбутнього митця. Технологія креативного навчання створює умови для розвитку творчих здібностей людини, активізує пізнавальну діяльність і спонукає до творчого мислення.

Дослідження проблеми розвитку творчих здібностей потребує з'ясування понять творчість та креативність. На пошуки універсального секрету творчості голландського режисера i продюсера Германа Васке, креативника агентства Saatchi\&Saatchi, колись надихнула суперечка 3 колегою Полом Аарденом. Не знайшовши відповіді, що влаштувала б їх обох, він вирішив поцікавитися, що 3 цього приводу думають найвидатніші творці сучасності. Протягом понад тридцяти років режисер-документаліст Герман Васке дізнавався про це від найвідоміших мислителів i творців планети: режисерів, акторів, музикантів, винахідників та вчених. Результатом масштабного опитування стала колекція з тисячі інтерв'ю, графічних записів, малюнків, книга, сайт, мобільний додаток i документальний кінофільм «Чому ми креативні», прем'єра якого відбулася на Венеційському кінофестивалі. Коли ж самого режисера запитали про те, що таке, на його думку, креативність, він запропонував зупинитися на тому, що креативність - це майстерність розпоряджатися власними ідеями [6].

Більшість дослідників схильні розглядати творчість як процес, що має певну специфіку й призводить до створення нового, а креативність - як потенціал, внутрішній ресурс людини, творчу здібність. Секрет креативності полягає в умінні генерувати дрібні ідеї у великий проект.

Креативний процес складається 3 поєднання відкритого і критичного мислення. У відкритому мисленні увага зосереджена на великій кількості самих оригінальних ідей, незалежно від можливостей їх реалізації та ступеня їх аргументованості. Але самі великі ідеї народжуються не миттєво, а виростають із дрібних у процесі тривалої, систематичної, наполегливої праці. Складність мислити по- 


\section{Вісник Національної академії керівних кадрів культури і мистецтв № 3’2020}

новому, коли потрібно створити щось нове, чого ще не було, знаходить пояснення у сформованих стереотипах. Стереотипи необхідні, вони полегшують нам життя. Проте можуть i заважати, якщо це стосується розробки креативного [3,245 ].

Невирішеним залишається питання про те, чи є креативність компонентом розумової та інших видів обдарованості, чи іiі варто розглядати як самостійний особливий вид обдарованості.

У контексті нашого дослідження інтерес представляють погляди дослідниці $\mathrm{H}$. Вишнякової, яка відносить креативність до складових професіоналізму. Вагомим $є$ й те, що вона виділяє творчу індивідуальність, яка, будучи вагомою характеристикою професійної творчості, визначається як інтегральна креативно-особова категорія, що об'єднує: інтелектуально-творчу ініціативу; інтелектуальні здібності; об'ємність та глибину знань; схильність до творчого сумніву; здатність вести внутрішню творчу боротьбу; відчуття новизни, уміння бачити незвичайне в проблемі; професіоналізм [2,18 ].

На сьогодні одним із першочергових завдань професійної підготовки високваліфікованих режисерів естради для дозвіллєвої сфери є формування креативного фахівця, який володіє певними особистісними властивостями. Крім того, аналіз проблеми формування креативного компонента дав змогу зазначити, що процес формування креативності об'єднує ряд певних характеристик: інтелектуальні особливості творчої діяльності, особистісні якості, що дають змогу продуктивно діяти в ситуації творчого вибору; творчі здібності, що передбачають відмову від стереотипності в судженнях $\mathrm{i}$ діях та $\epsilon$ основою творчої діяльності.

Професійна діяльність режисерів естради, event-режисерів включає художньо-творчу та виконавську діяльність, що безпосередньо пов'язана зі створенням якісного творчого продукту, організаційну роботу, важливим аспектом якої $\epsilon$ індивідуальний творчий стиль взаємодії як із аудиторією так і з конкретними людьми. Тому формування креативності як загальної здатності особистості до творчості $€$ важливою частиною підготовки майбутніх фахівців дозвіллєвої діяльності.

3 перших кроків навчання за спеціальністю 026 «Сценічне мистецтво» у мистецьких закладах вищої освіти, саме на заняттях 3 режисури закладаються основи професійної майстерності, креативного творчого мислення. Формування креативного творчого мислення стимулює мотиваційний компонент, розвиває пошукову самостійність і здатність долати труднощі, сприяє прагненню до досягнення кінцевого результату.

Для теоретичного та практичного забезпечення якісної фахової підготовки майбутніх бакалаврів 3 режисури естради головна увага приділяється основним завданням навчального курсу: засвоєння студентами теоретичних та практичних знань iз режисури естрадного номера, яка вивчає організацію, оволодіння студентами знань із структури номера як основи дійства; засвоєння студентами мистецтва компіляції синтетичного номера; оволодіння студентами практичних навичок із постановки естрадних номерів; проведення репетицій та постановку естрадних номерів на концертах, святах та урочистостях. Особлива увага звертається на вивчення психології естрадних артистів, специфіку естрадної драматургії, засоби емоційної та технічної виразності, види та жанри естради, побудову естрадного номеру, мініатюри, концерту, шоу-програми, масового дійства.

3 перших днів навчання здійснюється $\mathrm{i}$ професійна акторська підготовка студентів, без чого неможливе опанування режисерської техніки. Заняття 3 режисури і майстерності актора, окрім вивчення матеріалу навчальної програми систематично розвивають набуті навички на тренінгах, етюдах, продукують креативне творче мислення, i в цілому психофізичний стан студентів тримають в постійній творчій формі. Цей стан дозволяє студентам не тільки витримувати великі психічні та фізичні навантаження, а й поступово вдосконалювати режисерську майстерність.

Одним із основних факторів, що визначають успішність вивчення мистецтва режисури і майстерності актора, $\epsilon$ методика викладання. Щоденні заняття сприяють виробленню викладачем прийомів, доцільних для його складу студентів. Таким чином, створюється індивідуальна творча методика кожного викладача. Важливі аспекти якої полягають у тому, що вона пристосована до конкретних умов і грунтується на набутому професійному досвіді.

На нашу думку, неприпустимими $\epsilon$ уніфікація студентів, стирання творчих особливостей особистості. Протягом першого року занять для кожного студента створюються максимально комфортні умови для розкриття творчої індивідуальності, тобто 
виявлення діапазону акторських i режисерських талантів, щоб після закінчення курсу визначити можливість подальшого навчання студента за обраною професією.

Як показує практичний досвід, найкраще прослідковується індивідуальна результативність креативного творчого мислення студентів під час підготовки й проведення курсових семестрових студентських показів, що дозволяє зробити висновок про те, що домінуючою особливістю креативного компонента в підготовці майбутнього режисера $\epsilon$ високий рівень творчої активності, спрямованої на розвиток та реалізацію творчих здібностей у процесі підготовки майбутнього фахівця до професійної діяльності.

На наш погляд, креативність - це «майстерність розпоряджатися власними творчими ідеями», яку слід розглядати як основу, що зумовлює творчу активність людини для самоактуалізації та творчої самореалізації особистості у різних видах життєдіяльності. Отже, креативність є характерною ознакою творчої особистості, спроможної реалізовувати свій творчий потенціал за власною ініціативою і вибором відповідних засобів. для будь-якої творчої діяльності [2,14].

Тому важливе місце в навчальному процесі має бути відведено самостійній роботі як засобу формування самостійності як особистісної характеристики майбутнього фахівця дозвіллєвої сфери, що підвищує його пізнавальну, соціальну і професійну мобільність, створює у нього активне ставлення до навколишньої дійсності і до самого себе. Завдання педагога виявити ці особистісні якості i спонукати студента самостійно транслювати їх у мистецтво, навчити формулювати те, що турбує його в житті сценічними засобами. Для цього потрібно створити відповідні умови навчання, важливе місце в яких посідає індивідуалізація самостійного навчання.

Відмінною рисою самостійної роботи студентів $\epsilon$ те, що вона переважно здійснюється у практичній площині їхньої діяльності. Саме на практиці надається можливість проявити креативне мислення та творчу активність, перевірити та закріпити здобуті теоретичні знання в реальних умовах. Такий досвід активізує діяльність студента, підвищує його відповідальність за обрану справу, спонукає до вирішення творчих завдань.
Так, креативний компонент впливає на розвиток художньо-творчих умінь (виконавських, імпровізаційних), які, своєю чергою, формують професійно важливі якості: емпатію, артистизм, рефлексію, самостійність, творчу активність, ініціативність. Він стосується можливості не тільки споживати, а й діяти, творити, втілювати в життя власні переконання, містить орієнтири самореалізації особистості студента в процесі виконавської діяльності [7, 33].

Слід зазначити, що будь-яка самостійна робота передбачає i потребує педагогічної підтримки i уваги. Цей вид навчальної діяльності майбутніх режисерів естради направляється і контролюється педагогом. В процесі індивідуалізації самостійної роботи майбутніх режисерів самоконтроль в переважній кількості випадків стає домінантним, оскільки є запорукою найбільш якісної підготовки висококваліфікованого фахівця.

Вважаємо, що головним чинником навчання майбутніх режисерів естради за спеціальністю 026 «Сценічне мистецтво» $\epsilon$ креативне творче мислення викладачів i студентів у процесі фахового індивідуального начання, яке перетворюється у співпрацю викладача і студента. Велику роль при цьому відіграє особистість педагога, який має бути талановитою, яскравою, цікавою, творчою людиною. Креативність у підготовці майбутніх режисерів естради передбачає творче переосмислення результатів сприйняття i грунтується на нестандартному мисленні, знаннях законів драматургії та продюсування, реактивному реагуванні вирішення творчих завдань та індивідуально-особистісному підході до осягнення чіткого розуміння специфіки творчого процесу, генерування ідеї та інших творчих елементів.

Пошуки сучасної особистісно орієнтованої, креативної системи мистецької освіти майбутніх режисерів естради спрямовані на виявлення найефективніших форм i методів модернізації освітнього процесу.

Висновки. Теоретичний аналіз проблеми формування креативної компетентності майбутнього режисера естради дає змогу констатувати, що більша частина праць, які з'явилися останнім часом у науковому просторі, аналізують креативність у різних аспектах.

Розглянуто головні особливості та чинники формування креативного компонента фахової підготовки студентів-бакалаврів за 
спеціалізацією «Режисура естради та масових свят» спеціальності 026 «Сценічне мистецтво», для яких креативні здібності $\epsilon$ важливою творчою якістю та невід'ємною складовою фахової компетентності.

Встановлено, що формування креативного творчого мислення стимулює мотиваційний компонент, який розвиває пошукову самостійність і здатність долати труднощі, сприяє прагненню до досягнення кінцевого результату. Зазначено, що неприпустимими $\epsilon$ уніфікація студентів, стирання творчих особливостей особистості.

Проведене дослідження дає можливість зробити висновок про те, що домінуючою особливістю креативного компонента в підготовці майбутнього режисера естради $€$ високий рівень творчого саморозвитку особистості, що $є$ істотним резервом іiі самоактуалізації до професійної діяльності.

\section{Лimepamypa}

1. Антонова О. Є. Сутність поняття креативності: проблеми та пошуки. Теоретичні i прикладні аспекти розвитку креативної освіти у вищій школі : монографія. Житомир : Вид-во ЖДУ ім. І. Франка, 2012, 284 с.

2. Вишнякова Н.Ф. Психологические основы развития креативности в профессиональной акмеологии. Москва : Азбука-Аттикус, 1996. С. 31.

3. Джадкинс Р. Искусство креативного мышления / перев. с англ. П.Миронова. Москва : Азбука Бизнес, 2016. 432 c.

4. Зайцев В.П. Режисура естради та масових видовищ : навч. посібник для студ. вищих навч. закладів. Київ : Дакор, 2006. 251 с.

5. Креативність як майстерність розпоряджатися ідеями. URL : ttps://telekritika.ua/uk/kino/kreativnist-yak-majsternistrozporyadzhatisya-ideyami (Дата звернення 27.05.2019).
6. Творчість без меж. 7 виступів TED про креативність. URL

https://life.pravda.com.ua/society/2016/08/6/216219

(Дата звернення 24.05.2019).

7. Падалка Г.М. Педагогіка мистецтва (Теорія i методика викладання мистецьких дисциплін). Київ : Освіта України, 2010. 274 с.

8. Рождественская Н.В., Толшин А.В. Креативность : пути развития и тренинги. СанктПетербург : Речь, 2006. 320 c.

\section{References}

1. Antonova, O. E. (2012). The Essence of the Notion of Creativity: Problems and Quest. Theoretical and Applied Aspects of the Development of Creative Education in Higher Education: Monograph. Zhytomyr: Vyd-vo ZHDU im. Ivan Franko [in Ukrainian].

2. Vishnyakova, N. F. (1996). Psychological Foundations of Creativity Development in Professional Acmeology. Moscow : Azbuka-Atticus, 31 [in Russian].

3. Judkins, R. (2016). The Art of Creative Thinking. Moscow: Azbuka Business [in Russian].

4. Zaitsev, V.P. (2006). Direction of Stage and Mass Spectacles: Tutorial for students of higher education institutions. Kyiv: Dakor [in Ukrainian].

5. Creativity as a Skill to Dispose of Ideas. Retrieved from: https://telekritika.ua/uk/kino/kreativnist-yakmajsternist-rozporyadzhatisya-ideyami[in Ukrainian].

6. Creativity without Borders. 7 TED speeches about creativity. Retrieved from: https://life.pravda.com.ua/society/2016/08/6/216219/.[i n Ukrainian].

7. Padalka, G.M. (2010). Pedagogics of Arts (Theory and Methodology of Discipline of Arts). Kyiv: Osvita Ukrainy [in Ukrainian].

8. Rozhdestvenskaya, N.V., Tolshyn, A.V. (2006). Creativity: Ways of Development and Trainings. St. Petersburg : Rech [in Russian].

Стаття надійшла до редакиії 20.05.2020 Прийнято до друку 18.06.2020 